\title{
The Effect of Instagram's E-WOM on Netflix's Brand Image and Subscription Decision
}

\section{Pengaruh E-WOM di Instagram dan Citra Merek terhadap Keputusan Berlangganan Netflix}

\author{
Luk Lukul Hamidah ${ }^{1}$, Melvina Oktaviani ${ }^{2}$, Lestari Nurhajati ${ }^{3}$ \\ ${ }^{1,2,3}$ Institute of Communication and Business LSPR \\ ${ }^{1,2,3}$ Sudirman Park JL. KH. Mas Mansyur Kav.35, Jakarta, Indonesia \\ Email: ${ }^{1}$ luklukulhamidah@gmail.com
}

Received : June 13, 2021 ; Revised: July 28, 2021; Accepted: August 24, 2021

\begin{abstract}
The video-on-demand ( $\mathrm{VoD})$ business in Indonesia is currently proliferating, such as Netflix that is also available in 190 countries. Netflix began to enter the Indonesian market in 2016, and the subscribers keepincreasing, with only 100,000 subscribers in 2017 and raised to 906,810 subscribers in 2020. This controversy due to its content and age categorization, Netflix's subscribers grow unaffected. The role of Instagram's electronic word-of-mouth (e-WOM) has a significant influence on the marketing of a business, including Netflix. In this study, the theory of Elaboration Likelihood Model (ELM) was employed to analyze the influence of Instagram's e-WOM on brand image and subscription decision to Netflix. A total of 120 questionnaires was distributed across the Jabodetabek area (Jakarta, Bogor, Depok, Tangerang, and Bekasi), and the resulted dataset was quantitatively analyzed. This research also used path analysis to explore the direct and indirect effect of e-WOM on subscription decisions through brand image. The results showed that brand image positively and significantly strengthens the influence of eWOM on subscription decisions.
\end{abstract}

Keywords: brand image; e-WOM; Instagram; Netflix, subscription decision

\begin{abstract}
Abstrak
Bisnis video on demand $(\mathrm{VoD})$ di Indonesia seperti Netflix memasuki pasar Indonesia pada tahun 2016, dan pelanggannya terus meningkat, berawal dari 100.000 pelanggan pada tahun 2017 dan meningkat menjadi 906.810 pelanggan pada tahun 2020. Di tengah kontroversi yang terus berlanjut karena kategorisasi konten dan usia, pelanggan Netflix tumbuh tidak terpengaruh. Peran electronic word-of-mouth (e-WOM), Instagram memiliki pengaruh yang signifikan terhadap pemasaran suatu bisnis, termasuk Netflix. Teori Elaboration Likelihood Model (ELM) digunakan untuk menganalisis pengaruh eWOM Instagram terhadap citra merek dan keputusan berlangganan Netflix. Kuesioner disebarkan di seluruh wilayah Jabodetabek (Jakarta, Bogor, Depok, Tangerang, dan Bekasi) pada 120 responden. Data dianalisis secara kuantitatif dan menggunakan analisis jalur untuk mengeksplorasi pengaruh langsung dan tidak langsung e-WOM terhadap keputusan berlangganan melalui citra merek. Hasil penelitian menunjukkan bahwa citra
\end{abstract}


merek secara positif dan signifikan memperkuat pengaruh eWOM terhadap keputusan berlangganan..

Kata kunci: citra merek; e-WOM; Instagram; Keputusan Berlangganan; Netflix

\section{Introduction}

The rapid development of technology, especially the internet, has played a role in developing today's communication, which continues to experience rapid development. Social media is now a channel for people to share text, video, and audio, between individuals or even companies and consumers. Companies currently use social media presence as their marketing strategy (Kotler, 2012). There were 150 million, or about $56 \%$ of the Indonesian population, who have become active users on social media (Hootsuite \& We are social, 2020). From January to May 2020, Instagram users in Indonesia reached 69.2 million people and currently become the fourth most used social media in this nation. The popularity of Instagram makes it increasingly considered by various companies to be used as their communication media to market their products (Good News, 2020).

This concept of exchanging information through social media is referred to as electronic word-ofmouth (e-WOM). It is defined as a positive or negative statement made by consumers regarding a product or company, which people or institutions can access through the internet (Hennig-thurau et al., 2004). This concept of e-WOM is used by video-on-demand (VoD) services or a film or serial content provider platform whose users are currently proliferating in Indonesia. Several companies engaging in the $\mathrm{VoD}$ sector in Indonesia include Netflix, VIU, Iflix, MAX Stream, HBO GO, Disney+, GoPlay, Genflix, MNC Now, and Video.com.

In Indonesia, Netflix has been operating since 2016. However, its presence keeps reaping controversiesdue to its ethnic, religion, race, and intergroup (SARA) contents, such as lesbian, gay, bisexual, and transgender (LGBT), as well as pornographyrelated contents which are uncommon and not in accordance with norm and regulations in Indonesia (Alinea, 2020). However, although the negative news about Netflix continues, its users in Indonesia keep increasing. It is shown by the increase in the number of its users in Indonesia, which only 100,000 users in 2017 and reached 906,810 users in 2020 (Kompas, 2020).

Mathews et al. (2021) has found the positive impact of e-WOM on brand image in enhancing a business, whereby increasing proactive interactions on selected media can improve a brand image. The product's brand image can influence the purchasing decision of a product, i.e., the more favorable the image, the greater the influence on purchasing decisions (Ruslim \& Tumewu, 2015). One of the most effective ways to build a good brand image is e-WOM, which can 
significantly impact the brand image (Jalilyand \& Neda, 2012). A good image of a brand can also lead to a tendency for consumers to repurchase its product (Majid, 2013).

This study explores how the controversy of Netflix's contentsis contrary to the increase of its subscribers in Indonesia. Unfortunately, this kind of study still lacks in Indonesia. Therefore, this research tried to analyze the influence of Instagram's e-WOM on the brand image and subscription decision to Netflix.

\section{Theoretical Framework}

\subsection{Literature Review}

Kala and Chaubey (2018) tried to see the extent to which eWOM can affect the brand image and consumer buying interest in lifestyle products.It was found that through the intermediary variable, i.e., brand image, the e-WOM can influence consumers' interest in making purchases. Furthermore, the e-WOM variable is also a very effective way of influencing brand image and consumer purchase intentions for products on the market (Jalilvand \& Neda, 2012). The role of brand image as a mediator variable in eWOM that affects purchasing decisions has also been proven to significantly impact research on OPPO smartphone purchases in Sidoarjo (Purnamasari \& Yulianti, 2018).

In their research, Mathews et al. (2021) also found that a brand or company that proactively manages eWOM, in turn, provides positive benefits for increasing the reputation of the brand or company. In addition to influencing a company's performance, brand image can also change consumer attitudes when making purchases (Maliket al., 2013). Samuel and Lianto (2014) also found that e-WOM directly affects the brand image, trust, and buying interest. Brand image and brand trust are intermediate variables between e-WOM and purchase intention, strengthening the influence of e-WOM. The most significant finding of this study is that e-WOM positively affects the brand image and positively affects consumer buying interest.

Syafaruddin (2016) also concludes that consumer trust in brands or products is related to eWOM, impacting consumer confidence to make purchases. Some inputs were also conveyed by Padmawati et al. (2020) that the brand image should be appropriately built by paying attention to positive eWOM communication related to the superiority of its products and building good opinions so that it can generate consumer buying interest. Shahrinaz et al. (2016) also found a significant influence of brand image on consumers' purchase intentions. Therefore, marketers must understand and know the growing marketing concept using e-WOM because it impacts purchasing decisions (Fitria et al., 2016).

\subsection{Elaboration Likelihood Model (ELM)}

The Elaboration Likelihood Model (ELM) theory has proven helpful in marketing, advertising, health communication, law, environment, politics, and education. One of the reasons ELM is so widely 
applied is because persuasion is ubiquitous. People try to persuade others and become targets of that persuasion (Petty \& Briñol, 2012).

ELM can serve as a basis and explain various phenomena that are not only relevant to attitude change but also for various other judgments that can influence choices and decision-making (Griffin, 2012).

In ELM theory, there are two pathways for a person's cognitive processes in thinking about the messages they receive, i.e., the central route and the peripheral route. Messages received by individuals are processed with great care, deep and systematic thinking that can finally influence the attitudes and responses of the recipients of the message for the central route. Meanwhile, on the peripheral route, the message recipient will not think critically or deeply about the strength or weakness of the message received. Instead, thelatter recipients rely on simple instructions regardless of whether the message's argument is strong or weak to quickly decide whether to accept or reject the message (Morissan, 2013).

\subsection{WOM to e-WOM}

Word-of-mouth (WOM) is the oldest way to convey information (Dellarocas, 2003) and has been defined in many ways. One of the earliest definitions was proposed by Katz and Lazarsfeld (1966), where there is an exchange of information between consumers, which can further influence consumer attitudes and behavior towards products or services.

According to Litvin et al. (2008), the concept of e-WOM itself is an exchange of information between consumers that occurs via the internet and is information that helps find out about the characteristics of products or services. The advantage of e-WOM is that consumers can easily share comments and opinions through the online platform with other users.

The internet has enabled the emergence of new communication platforms to empower providers and consumers better, enabling them to share information and opinion, both Business-to-Consumer (B2C) and Consumer-to-Consumer (C2C). The new form of WOM communication is now online and known as electronic Word-of-Mouth (Yang, 2017).

Social media is defined as an internet-based service that creates an environment where people can create networks and private data while enabling them to access other people's networks and private data (Boyd \& Ellison, 2007). The emergence of social networks has developed various forms of communication, making it easier and faster for consumers to connect, create, publish, and share their content through Facebook, Youtube, Twitter, Instagram, and other media (Daugherty and Hoffman, 2013).

Instagram is an app that allows users to share photos and videos. As Instagram becomes more popular as a photo-sharing app, many users are jumping into the business world, such as social accounts promoting products through Instagram for commercial purposes (Nisrina, 2015).

Hennig-Thurau et al. (2004) described WOM through eight 
dimensions, i.e., platform assistance, venting negative feelings, concern for other consumers, extraversion/positive selfenhancement, social benefits, economic incentives, helping the company, and advice seeking. This study will adoptonly four dimensions, i.e., concern for others, expressing positive feelings, helping the company, and platform assistance.

\subsection{Brand Image}

Brand image or brand descriptions describe consumers' association and beliefs of a particular brand (Tjiptono, 2011). (Aaker, 1991) defined brand image as a series of the brand involvement stored in the consumer's mind. Brand image is related to the cognition of a brand, which is created in the consumer's mind through brand involvement (Keller, 2008). In addition, the brand image also plays an essential role in enhancing the company's performance as it is an indirect method capable of changing consumer buying behavior (Malik et al., 2013).

The purchase of a brand is related to a strong positive image (Khanna et al., 2007). Therefore, a brand with a strong positive image may lead to consumer intention to buy, while those with a negative image could not lead consumer intention to buy. Therefore, Cronin (1992) stated that a consumer's decision to purchase depends on the brand image received by the consumer.

According to Aaker (2000), six benchmark factors of brand image are product attributes, consumer benefit, brand personality, user imagery, organizational association, and brand-customer relationship. Each of these is explained as follows, respectively. First, a brand can bring out particular attributes on their products or services, leaving particular memory in consumers'minds to remind them of the brand'scharacteristics. Second, a brand must provide value and benefit when consumers buy or consume its products or services. Third, a brand with a series of personal characteristics which the consumer will associate with a particular brand. Fourth, user imagery is defined as a series of human characteristics gathered in an association with the type of consumers who use or consume the brand. Five, consumers often associate the product purchased with the credibility of the manufacturer. Finally, a brand must be able to create a good relationship with its consumers.

\subsection{Purchasing Decision}

In this research, subscription decision is similar to purchasing decision. According to Kotler and Armstrong (2007), purchasing decision is a final stage in the purchasing decision-making process where consumers finally purchase the product. In deciding, a consumer will go through several stages. The following are several stages in the process of purchasing decisionmaking, according to (Kotler 2012). The first stage, i.e., recognition of needs. When consumers recognize their needs, they will understand which needs must be fulfilled immediately and can not be delayed. Second ,i.e., 
information search. When someone recognizes their needs, they will look for further information about the product to be purchased. Third, i.e., evaluation of alternatives. After getting as much information as possible, consumers will use it to evaluate alternatives into an order of choices. The fourth stage is the purchasing decision. Even when deciding, there is usually a particular behavior of individuals. The situation can depend on the others. For example, if the consumer decides to purchase, the consumer will encounter several decisions regarding the type of, time to, and method to purchase. Lastly, the postpurchase behavior. Post-purchase behavior becomes a concern to marketers. Consumers will experience a series of satisfaction or dissatisfaction after purchasing a product, and the consumer may be dissatisfied due to a mismatch between their expectations and reality.

Three hypotheses that would be tested in this study are as follows. H1: There is an influence between eWOM on Netflix brand image. H2: There is an influence between the brand image on the decision to purchase a Netflix subscription. H3: There is a collective influence between e-WOM and brand image on the decision to purchase a Netflix subscription.

\section{Research Method}

This research is explanative quantitative. The explanative format is intended to explain a generalization of the sample to the population or explain the relationship, differences, or influence between variables (Figure 1). Therefore, explanative research uses a sample and hypothesis. This research with the explanative format can be conducted through surveys or experiments (Bungin, 2009).

The population in this research are users or potential users around Jakarta, Bogor, Depok, Tangerang, and Bekasi (Jabodetabek) area. The sample of this research involved 100 respondents by using a purposive sampling technic. Several criteria are used to select the respondents, including those who had subscribed, are currently subscribing, and follow Netlfix's Instagram account (@netflixid).

The analysis technique is using path analysis. Path analysis can be used to determine causality to explain the direct and indirect effects of a collection of independent or exogenous variables from the dependent or endogenous variables (Riduwan and Kuncoro, 2007). 


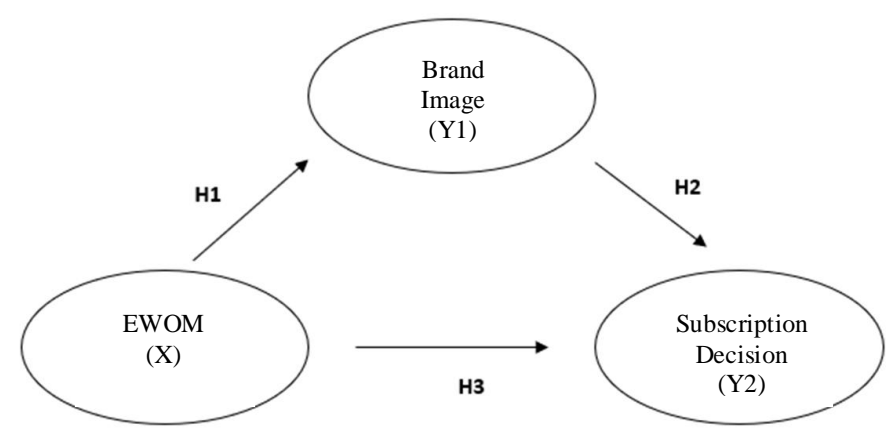

Figure 1. Theoretical framework

\section{Findings and Discussion}

\subsection{Validity and Reliability Test}

Validity rest result with the Pearson Correlation on electronic Word-ofMouth (e-WOM), brand image, and subscription decision questionnaire, showing that if the $r$ count value of each item meets the requirement (larger than 0.361 ), the item is valid and able to be continued for further analysis.
The reliability test result with Cronbach Alpha showing that the Cronbach Alpha value meets the requirement (larger than 0.6) so that the variable is reliable. Information obtained from the questionnaire (analyzed with SPSS) shows that the variables used in this research are reliable, as shown in Table 1.

Table 1. Cronbach Alpha Value

\begin{tabular}{|l|l|l|l|}
\hline Variable & Cronbach Alpha & N of items & Reliability \\
\hline E-WOM & 0.884 & 13 & Reliable \\
\hline Brand Image & 0.885 & 9 & Reliable \\
\hline Subcription Decision & 0.656 & 5 & Reliable \\
\hline
\end{tabular}

Source: Processed research data (2021)

\subsection{Hypothesis Result}

Based on the results of hypothesis testing obtained through the path coefficient (Figure 2), it can be concluded that the effect of e-WOM on brand image is 0.448 higher than the direct effect of e-WOM on subscription decisions of 0.220 . In addition, from the path coefficient, it is also found that brand image significantly influences consumer decisions to purchase Netflix products by 0.470 . Thus, the results of this study have similarities to previous studies that the role of brand image as a mediator variable in e-WOM that affects purchasing decisions has also been proven to have a significant impact on research on OPPO smartphone purchases 
Sidoarjo (Purnamasari \& Yulianti, 2018).

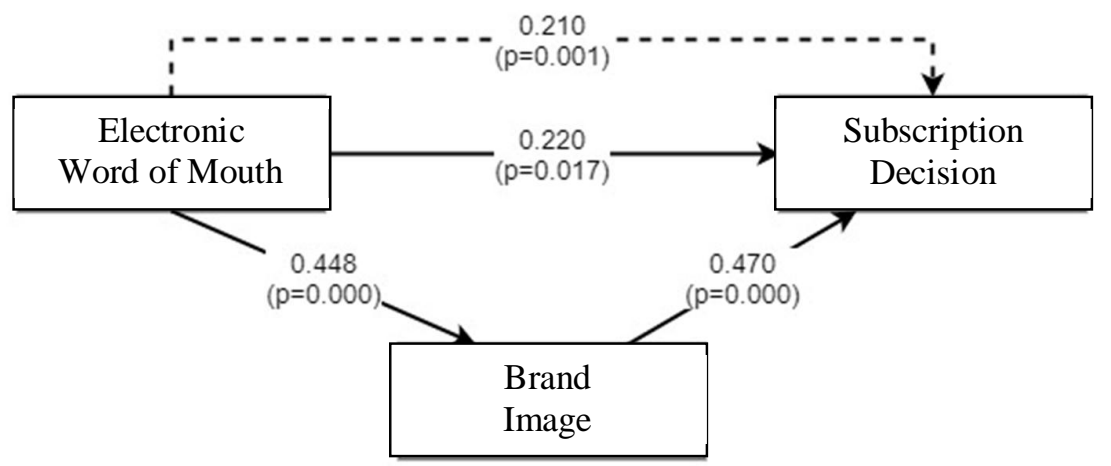

Figure 2. Diagram of path analysis.

Source: Research output data (2021)

In their research, Mathews et al. (2021) also found that a brand or company that proactively manages eWOM, in turn, provides positive benefits for increasing the reputation of the brand or company. In addition to influencing a company's performance, brand image can also change consumer attitudes when making purchases (Malik, Ghafoor, Iqbal, et al., 2013). Syafaruddin Z (2016), in his research, also concludes that consumer trust in brands or products is related to the formed e-WOM, which has an impact on consumer confidence to make purchases. So, marketers must understand and know the growing marketing concept using e-WOM because it impacts purchasing decisions (Fitria, Sisca Eka \& Dwijananda, 2016).

The researcher found that based on the results of respondents' answers, data obtained that the eWOM that took place on Instagram related to Netflix so far was positive so that it affected the formation of Netflix's reputation in the minds of consumers. The success of e-WOM on Instagram in forming a positive
Netflix image is what ultimately becomes the basis for consumer decision-making in Jabodetabek to make a purchase. Some inputs were also conveyed by Padmawati et al. (2020), which was obtained from the results of his research that the brand image should be appropriately built by paying attention to positive eWOM communication related to the superiority of its products and being able to build good opinions so that the public can make consumers make purchases.

It was found that the respondents could be said to make maximum use of the Instagram platform to find and share information and experiences related to Netflix. Furthermore, the average value on the platform assistance and venting negative feeling dimensions is the highest at 3.93 and 3.95 so that consumers do agree that Instagram is an effective platform to get information related to Netflix so that it acts as a channel for respondents' disappointment and prevents others experienced the same thing with the Netflix service. 
Meanwhile, in Variable Y1, namely the brand image contained in the nine statements, it is found that on the average dimension, the respondents agree with the corporate image about Netflix that has been formed through e-WOM on Instagram. There are two dimensions with a high mean value through the six dimensions, namely, related to product attributes and consumer benefits. Here respondents agree that the features offered by Netflix are indeed able to provide convenience.

In this study, subscription decision variable (Y2) found two statements out of five with a high mean value: a sense of satisfaction of consumers having chosen Netflix at 4.04 and their desire to continue to subscribe to Netflix 4.06. So, through this study, respondents said that their decision to subscribe to Netflix was right after doing some thinking.

In the Elaboration of Possibility Theory (ELM), it is assumed that a person can be motivated based on the opinions, which are then processed and elaborated consciously, meaning that the person processes them with a central route. In this study, respondents consciously read or search for information on Instagram related to Netflix to get complete information about the services offered before deciding to buy. The conceptual rationale used in this study refers to the ELM theory, and the results also show that e-WOM related to Netflix on the Instagram social network influences the formation of brand image in the eyes of consumers. The brand reputation for products or services that consumers have received is the basis for them to behave in purchasing products, which is a Netflix subscription.

\subsection{Impact of e-WOM on Brand Image}

Based on the results of the hypothesis above, it is evident that through the Instagram account, users can find positive recommendations from their relationship, or through the official @netflixid account, regarding the services provided by Netflix. Furthermore, through eWOM, customers feel that these positive recommendations have a significant direct impact on Netflix's brand image, to be taken into consideration when making a purchase; the more positive information that is spread through Instagram about the Netflix service, the more positive the brand image created in the eyes of consumers. For example, suppose it is associated with the ELM concept. In that case, it can be concluded that e-WOM on Instagram about Netflix through the eight dimensions of e-WOM can have an impact on the reputation of a brand or company so that interactions that occur on Instagram must be the attention of marketers in order to continue to have a positive impact on the company.

\subsection{Impact of Brand Image on Subscription Decisions}

The research results found by the author are in accordance with the research hypotheses that have been determined previously. Through brand image variables consisting of product service quality, product benefits, and features provided, the relationship between brands and 
consumers is positive and can significantly impact potential consumers to subscribe to Netflix. The positive image in the eyes of today's consumers is a significant factor that can convince them to subscribe to Netflix.

4.5. Impact of e-WOM on Subscription Decisions through Brand Image

The hypothesis of this study significantly indicates that e-WOM has a significant effect on subscription decisions through the intervening variable, namely brand image; the more positive messages that are spread through e-WOM, the better the impact on consumer subscription decisions. One of the considerations for using a product is influenced by the brand image created; the more positive the image of a product, the better the impact on consumer subscription decisions. This positive EWOM, both in recommendations and reviews of Netflix services, can maximize product sales.

\section{Conclusion}

This study founds that the e-WOM that took place on Instagram had a significant influence on the Netflix brand image in the minds of consumers. The brand image indicates that the higher the positive e-WOM quality, the more positive the brand image. Therefore, a positive image of a brand will influence consumers to make purchases. This resulting study is also supported by Cronin (1992) that consumer subscription decisions are very dependent on the brand image received by consumers. Furthermore,
Hasan (2010) also found that this source of WOM information became the basis for strengthening WOM consumers in making subscription decisions and seeking deeper information. Therefore, building an image that will impact consumer subscription decisions through positive and high e-WOM can provide a sustainable influence. In this study, it was found that the direct influence of e-WOM (X) on the brand image $(\mathrm{Z})$ and subscription decisions (Y) was $24,7 \%$, then $75,31 \%$ was directly influenced by several things or other factors which were not analyzed at this time.

The researcher hopes that in further research, several other factors other than the influence of e-WOM on Instagram on the Netflix brand image can be found that can influence consumer subscription decisions. The existence of this research can also be a suggestion for the Netflix marketing team to continue to increase eWOM activities, especially on Instagram, one of which is to provide the best service and always present up-todate shows so that the reviews shared by customers are more positive and influence other potential customers to decide to subscribe. Some of the features provided by Instagram are also increasingly diverse that can be used to attract attention. Moreover, seeing the increasing number of competitors in the VOD service market, Netflix must continue to provide the best service so that positive EWOM continues to be shared by consumers. 


\section{References}

Book:

Aaker, D. A. (2000). Managing Brand Equity. New York: Free Press.

Bungin, B. (2009). Metode Penelitian Kuantitatif. Jakarta: Kencana.

Griffin, EM. (2004). A First Look At Communication Theory. New York: McGraw-Hill

Hasan, Ali. (2010). Marketing dari Mulut ke Mulut. Yogyakarta: Media Pressindo

Hootsuite\& We are Social. (2020). Indonesian Digital Report 2020. Singapore: Hootsuite.

Keller, K. K. (2008). Strategic Brand Management: building, measuring, and managing brand (4th edition). In Pearson/Prentice Hall.

Kotler, Philip dan Keller. (2007). Manajemen Pemasaran, Jilid I, Edisi Kedua belas. Jakarta: PT. Indeks

Kotler, P., Keller, K. L. (2012). Marketing management/Philip Kotler, Pearson Educ Int. Pearson Education International.

Morissan. (2013). Teori Komunikasi Individu Hingga Massa. Jakarta: Kencana Prenamedia Group.

Nielsen. (2013). Global Trust in Advertising. New York: Nielsen.

Tjiptono, Fandy. (2001). Strategi Pemasaran. Edisi Pertama. Yogyakarta: Andi Ofset

Internet:
Iman, M. (2020). Good News. Retrieved from goodnewsfromindonesia.id website:

https://www.goodnewsfromind onesia.id/2020/06/14/pengguna -instagram-di-indonesiadidominasi-wanita-dangenerasi-milenial

Statista, The Statistics Portal. Retrieved from goodnewsfromindonesia.id website: http://www. goodnewsfromindonesia.id statistics/199242/social-mediaand-networking/sites-used-byus-teenagers/

Journal article:

Aaker, D. A. (1991). Managing Brand Equity. Journal of Marketing.

Cronin Jr, J. J., \& Taylor, S. A. (1992). Measuring service quality: A reexamination and extension. The Journal of Marketing, 55-68. https://doi.org/10.2307/125229

$$
6
$$

Devkant, Kala \& D. S. Chaubey. (2018). The effect of eWOM communication on brand image and purchase intention towards lifestyle products in India, International Journal of Services, Economics, and Management, Inderscience Enterprises Ltd, vol. 9(2), pages 143-157.

Fitria, S. E., Dwijananda, I. M. (2016). Analisis Pengaruh Electronic Word of Mouth Terhadap Proses Keputusan Pembelian. 3(1), 1-20.

Gutomo, A. (2016). Pengaruh Terpaan Tayangan Film 
Melalui Rute Peripheral Dalam Elaboration Likelihood Model Terhadap Brand Loyalty pada Brand Community

Hennig-Thurau, T., Eifler, V., Hennig-thurau, T., Gwinner, K. P., \& Gremler, D. D. (2004). Electronic Word-of-Mouth Via Consumer-Opinion Platforms : What Motivates Consumers To Articulate Themselves On The Internet ? $18(1)$. https://doi.org/10.1002/dir.100 73

Jalilvand, M. R., \& Neda, S. (2012). The Effect of Electronic Wordof-Mouth on Brand Image and Purchase Intention. Journal of Marketing Intelligence And Planning, 5.

Khanna, D., Yan, X., Tashkin, D. P., Furst, D. E., Elashoff, R., Roth, M. D., \& Seibold, J. R. (2007). Impact of oral cyclophosphamide on health related quality of life in patients with active scleroderma lung disease: Results from the scleroderma lung study. Arthritis \& Rheumatism, 56(5), 1676-1684. https://doi.org/10.1002/art.2258 $\underline{0}$

Litvin, S. W., Goldsmith, R. E., \& Pan, B. (2008). Electronic Word-of-Mouth in hospitality and tourism management. Tour. Manage. 29, 458-468. https://doi.org/10.1016/j.tourm an.2007.05.011

Majid, N. (2013). Analisis Pengaruh Electronic Word of Mouth terhadap Brand Image dan Dampaknya pada Minat Beli Smartphone Samsung di Kota Malang Oleh. Journal of
Chemical Information and Modeling, 53(9), 1689-1699.

Malik, M. E., Ghafoor, M. M., Iqbal, H. K., Ali, Q., Hunbal, H., Noman, M., \& Ahmad, B. (2013). Impact of brand image and advertisement on consumer buying behavior. World Applied Sciences Journal, 23(1), 117-122.

Mathews, S., Prentice, C., Tsou, A., Weeks, C., Tam, L., \& Luck, E. (2021). Managing eWOM for hotel performance. Journal of Global Scholars of Marketing Science.

https://doi.org/10.1080/216391

59.2020.1808844

Padmawati, Ni \& Suasana, Igakg. (2020). Peran Kepercayaan Merek Dalam Memediasi Pengaruh E-Wom Terhadap Keputusan Pembelian Produk Chatime Di Bali. E-Jurnal Manajemen Universitas Udayana. $\quad 9.2621$. https://doi.org/10.24843/EJMU NUD.2020.v09.i07.p08.

Petty, R. E., \& Briñol, P. (2012). The elaboration likelihood model. Handbook of Theories of Social Psychology: Volume 1, January, 224-245. https://doi.org/10.4135/978144 6249215.n12

Purnamasari, D., \& Yulianti, E. (2018). Analisis Electronic Word Of Mouth Terhadap Keputusan Pembelian Produk Smartphone Oppo Dengan Brand Image Dan Brand Trust Sebagai Variabel Moderator (Survei Pada Konsumen Oppo Shop Center Sidoarjo). Jurnal Administrasi Bisnis, 92-100. 
Shahrinaz, Irwan \& Kasuma, Jati \& Yacob, Yusman \& Dayang, Hummida \& Abang, Abdul \& Rahman, \& Mahdi, Ahmad. (2016). Relationship and impact of e-WOM and brand image towards purchase intention of smartphone? Journal of Scientific Research and Development. 3. 117-124.

Syafaruddin Z, Suharyono, Srikandi Kumadjin. (2016). Pengaruh Komunikasi Electronicword of Mouth Terhadap Kepercayaan
(Trust) Dan Niat Beli (Purchase Intention) Serta Dampaknya Pada Keputusan Pembelian. Jurnal Bisnis Dan Manajemen, 3(1): 65-72.

Yang, F. X. (2017). Effects of restaurant satisfaction and knowledge sharing motivation on eWOM intentions: the moderating role of technology acceptance factors. J. Hosp. Tour. Res. 41, 93-127. https://doi.org/10.1177/109634 8013515918 